\title{
Isolation of BAC clones spanning the Xq22.3 translocation breakpoint in a lissencephaly patient with a de novo $\mathrm{X} ; 2$ translocation
}

\author{
Naomichi Matsumoto, Daniela T Pilz, Judy A Fantes, Kirk Kittikamron, \\ David H Ledbetter
}

Department of Human Genetics, The University of Chicago, 924 E 57th Street, Chicago, IL 60637, USA

N Matsumoto

D T Pilz

J A Fantes

K Kittikamron

D H Ledbetter

Correspondence to:

Dr Ledbetter.

Received 26 December 1997 Revised version accepted for publication 2 March 1998

Table 1 Published STS

\begin{abstract}
$\mathbf{X}$ linked lissencephaly and subcortical band heterotopia (XLIS/SBH) is a disorder of cortical development, which causes classical lissencephaly with severe mental retardation and epilepsy in hemizygous males and SBH associated with milder mental retardation and epilepsy in heterozygous females. Here we report the fine mapping of a breakpoint involved in a de novo $X$;autosomal balanced translocation (46,XX,t $X ; 2)(q 22.3 ; p 25.1)$ previously described in a female with classical lissencephaly. We constructed a complete $490 \mathrm{~kb}$ BAC contig around the Xq22.3 breakpoint with 11 novel STSs and isolated three BAC clones spanning the breakpoint. This mapping information and BAC contig will be useful in the detailed characterisation of the XLIS gene and other contiguous genes which may also be involved in brain development or function.

(F Med Genet 1998;35:829-832)
\end{abstract}

Keywords: X linked lissencephaly; X;autosome translocation; positional cloning

Malformations of neuronal migration such as lissencephaly are an important cause of mental retardation and epilepsy. Classical lissencephaly and cobblestone lissencephaly are two

\begin{tabular}{|c|c|c|c|}
\hline Primer name & Sequences $\left(5^{\prime} \rightarrow 3^{\prime}\right)$ & $\begin{array}{l}\text { Product size } \\
(b p)\end{array}$ & $\begin{array}{l}\mathrm{Ta} \\
(\mathrm{C} C)\end{array}$ \\
\hline $\begin{array}{l}\text { sWXD500a } \\
\text { sWXD500b }\end{array}$ & $\begin{array}{l}\text { GGC CGT CAT TAG TGC TGG } \\
\text { GCA AGA TAT GAA TCC TGG AG }\end{array}$ & 440 & 55 \\
\hline sWXD1665a & GGG GAA GGA AGG GAA AAA & 97 & 55 \\
\hline sWXD1665b & GTA TGA TAA GCA TAA TAC AAA TGA CC & & \\
\hline $\begin{array}{l}\text { sWXD1198a } \\
\text { sWXD1198b }\end{array}$ & $\begin{array}{l}\text { CCT AAT AAA CAC CAG GCA C } \\
\text { GTA TGA TAA GCA TAA TAC AAA TGA CC }\end{array}$ & 71 & 50 \\
\hline $\begin{array}{l}\text { sWXD2961a } \\
\text { sWXD2961b }\end{array}$ & $\begin{array}{l}\text { CAT CTG GCA ACT TAA AGT GG } \\
\text { CTG GAC TAG GAT TTG ATT CTT GG }\end{array}$ & 141 & 55 \\
\hline $\begin{array}{l}\text { sWXD1689a } \\
\text { sWXD1689b }\end{array}$ & $\begin{array}{l}\text { GGA GAA ATG GGG AGT AAC TG } \\
\text { ACA CAT GGC TGG CTA GCT T }\end{array}$ & 276 & 55 \\
\hline $\begin{array}{l}\text { sWXD1607a } \\
\text { sWXD1607b }\end{array}$ & $\begin{array}{l}\text { TAT TTA CAG CAT GGT TTA CTT GAA } \\
\text { ATA CAT CTA TCC CTA CAC AGT TAC G }\end{array}$ & 123 & 55 \\
\hline $\begin{array}{l}\text { sWXD1880a } \\
\text { sWXD1880b }\end{array}$ & $\begin{array}{l}\text { CTT GGG GAG CCT GCT AA } \\
\text { TGC TAT CAA CCA GTT CAG CC }\end{array}$ & 184 & 55 \\
\hline $\begin{array}{l}\text { sWXD2045a } \\
\text { sWXD2045b }\end{array}$ & $\begin{array}{l}\text { GGG GGG TTA ATG AAT AAA TGG } \\
\text { TAG AAG GGG ATG CTG AGT G }\end{array}$ & 171 & 55 \\
\hline $\begin{array}{l}\text { sWXD2044a } \\
\text { sWXD2044a }\end{array}$ & $\begin{array}{l}\text { GGT AGG ATG AGG AAA GTA ATG } \\
\text { CCT CTG TAG GCT TGC TTA ATG }\end{array}$ & 120 & 55 \\
\hline $\begin{array}{l}\text { sWXD1961a } \\
\text { sWXD1961b }\end{array}$ & $\begin{array}{l}\text { CTA TTC TAG GTC TTC TGC ATT TC } \\
\text { TCT TAG GAA TTG ATG AGC AGG }\end{array}$ & 60 & 55 \\
\hline $\begin{array}{l}\text { sWXD497a } \\
\text { sWXD497b }\end{array}$ & $\begin{array}{l}\text { GTA TGC AAC ACC ACC ATC C } \\
\text { GTA TTT CCA CAG CCT TCT TGA G }\end{array}$ & 66 & 55 \\
\hline $\begin{array}{l}\text { sWXD2043a } \\
\text { sWXD2043b }\end{array}$ & $\begin{array}{l}\text { CCC AAA TAT CCT GGA AAA CC } \\
\text { CCG TGT AGT TAA AAT TAT GTT GTT C }\end{array}$ & 79 & 55 \\
\hline $\begin{array}{l}\text { sWXD2425a } \\
\text { sWXD2425a }\end{array}$ & $\begin{array}{l}\text { GGT TTT CCT TTG GCG TAT GAC } \\
\text { CTA CTA TCA ATC CTA CCC AGA G }\end{array}$ & 101 & 55 \\
\hline
\end{tabular}

Ta: annealing temperature. pathologically and radiologically well defined types of this disorder. Other types such as microlissencephaly (associated with severe microcephaly and cerebellar hypoplasia) are being increasingly recognised. ${ }^{1}$ Classical lissencephaly is characterised by gyral abnormalities ranging from agyria to pachygyria, a thick cerebral cortex, hypoplasia of the corpus callosum, and incomplete opercularisation. Its spectrum also includes subcortical band heterotopia. The cerebellum usually appears normal. It is associated with three major syndromes: Miller-Dieker syndrome (MDS), isolated lissencephaly sequence (ILS), and X linked lissencephaly (XLIS)/subcortical band heterotopia (SBH). ${ }^{2}$ Facial dysmorphism is recognised in MDS, but is mild or absent in ILS and XLIS. Additional malformations are also predominantly seen in MDS. ${ }^{3-5}$

Genetic causes in classical lissencephaly have been elucidated. MDS is associated with visible or submicroscopic rearrangements within chromosome band $17 \mathrm{p} 13.3$ in almost all patients. In ILS, submicroscopic deletions of chromosome 17p13.3 have been detected in approximately $40 \%$ of cases $^{6}$ (Pilz et al, submitted). The LIS1 gene has been mapped to the $17 \mathrm{p} 13.3$ deletion region ${ }^{78}$ and several mutations of the LIS1 gene have been found in ILS patients without deletions. ${ }^{9} 10$

XLIS and SBH can be present with sporadic or familial mental retardation and epilepsy. The brain malformation varies from classical lissencephaly, which is observed in males, to $\mathrm{SBH}$, which is observed primarily in females. The XLIS gene is located at Xq22.3 based on the observation of a female lissencephaly patient with a de novo $X$;autosome translocation ${ }^{411}$ and two recent linkage studies on XIIS/SBH families. ${ }^{12}{ }^{13}$ Physical mapping studies of the XLIS/SBH region using the $t(X ; 2)$ patient showed that the Xq22 breakpoint lies between the anchor markers DXS1105 and DXS1072, which are located within $1 \mathrm{cM}$ of each other on the Genethon map. ${ }^{13}$

Here we describe the isolation of $\mathrm{BAC}$ clones spanning the Xq22 breakpoint of $t(X ; 2)$ in a lissencephaly patient and the construction of a $490 \mathrm{~kb}$ bacterial artificial chromosome (BAC) contig around the breakpoint.

\section{Materials and methods} CELL LINES

A lymphoblastoid cell line was previously made from a girl (XII-01) with classical lissencephaly and the karyotype $46, \mathrm{X}, \mathrm{t}(\mathrm{X} ; 2)$ 
Table 2 Isolated BAC clones with region specific STSs and FISH localisation

\begin{tabular}{|c|c|c|}
\hline$B A C$ clone & STSs & FISH analysis \\
\hline$\overline{4707}$ & $\begin{array}{l}\text { sWXD500 } \\
\text { sWXD1665/1198 } \\
\text { sWXD2961 }\end{array}$ & $\mathbf{P}$ \\
\hline $76 P 19$ & $\begin{array}{l}\text { sWXD500 } \\
\text { sWXD1665/1198 } \\
\text { sWXD2961 }\end{array}$ & $\mathbf{P}$ \\
\hline 90P19 & sWXD2961 & $\mathbf{P}$ \\
\hline $97 \mathrm{~N} 17$ & sWXD1689 & $\mathbf{P}$ \\
\hline $175 \mathrm{~L} 4$ & $\begin{array}{l}\text { sWXD1689 } \\
\text { sWXD1607 }\end{array}$ & $\mathbf{P}$ \\
\hline 268L20 & sWXD1880 & $\mathbf{P}$ \\
\hline $37 \mathrm{G} 4$ & sWXD2045 & $\mathbf{P}$ \\
\hline $278 \mathrm{H} 4$ & sWXD2045 & $\mathbf{P}$ \\
\hline $35 \mathrm{~L} 6$ & sWXD2044 & B \\
\hline $163 \mathrm{I} 7$ & sWXD2044 & B \\
\hline $183 N 12$ & sWXD2044 & B \\
\hline $127 \mathrm{H} 8$ & sWXD2044 & D \\
\hline $162 \mathrm{M} 18$ & $\begin{array}{l}\text { sWXD1961 } \\
\text { sWXD497 }\end{array}$ & D \\
\hline $115 \mathrm{I} 2$ & $\begin{array}{l}\text { sWXD497 } \\
\text { sWXD2043 } \\
\text { sWXD2425 }\end{array}$ & D \\
\hline $\begin{array}{l}75 \mathrm{C} 8 \\
262 \mathrm{~J} 17\end{array}$ & $\begin{array}{l}\text { sWXD2425 } \\
\text { sWXD2425 }\end{array}$ & $\begin{array}{l}\mathrm{D} \\
\mathrm{D}\end{array}$ \\
\hline
\end{tabular}

P: clone mapped proximal to the breakpoint. B: clone spanning the breakpoint. D: clone mapped distal to the breakpoint.

(q22.3;p25.1) de novo. ${ }^{413}$ A lymphoblastoid cell line with a normal karyotype was also used as a control. The patient's lymphoblastoid cell line and a somatic cell hybrid containing one of the breakpoints (the derivative chromosome 2, without the normal $\mathrm{X}$ or the derivative $\mathrm{X}$ chromosome present) were deposited in the NIGMS Human Genetic Mutant Cell Repository at the Coriell Insititute (GM12514 and GM12515, respectively).

BAC CLONE ISOLATION

All BAC clones were obtained by PCR screening of a BAC library (Genome Systems, St Louis, MO) according to the manufacturer's protocol. Region specific STSs between DXS287 and DXS1072 $2^{13}$ were obtained from an X chromosome map at $75 \mathrm{~kb}$ STS resolution. ${ }^{14}$ Primer sequences used here are

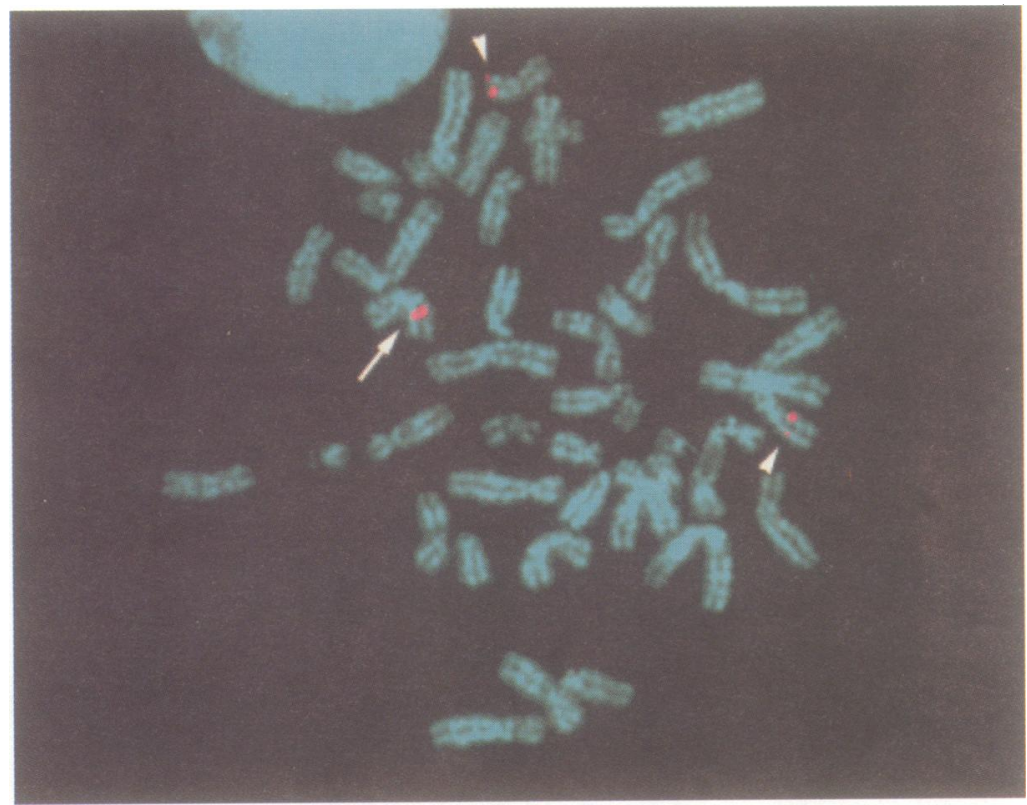

Figure 1 FISH analysis of the translocation patient's chromosomes using $183 N 12$ as a probe. Arrow indicates a signal on a normal chromosome $X$, and arrowheads indicate signals on both the der $(X)$ and the der(2) chromosomes. shown in table 1. PCR was performed for 35 cycles at $94^{\circ} \mathrm{C}$ for 30 seconds, at $50-55^{\circ} \mathrm{C}$ for 30 seconds, and at $72^{\circ} \mathrm{C}$ for 30 seconds.

FLUORESCENCE IN SITU HYBRIDISATION

Chromosome preparations were made fror lymphoblastoid cell lines by conventiong methods. Slides were incubated in $2 \times$ SSC at $37^{\circ} \mathrm{C}$ for 30 minutes, serially dehydrated $i \overrightarrow{\vec{n}}$ $70 \%, 80 \%$, and $95 \%$ ethanol at room tempera ture, denatured in $70 \%$ formamide $/ 2 \times$ SSC $72{ }^{\circ} \mathrm{C}$ for two minutes, then serially dehydrate in $70 \%, 80 \%, 90 \%$, and $100 \%$ ethanol (拿 $-20^{\circ} \mathrm{C}$ ).

BAC DNAs were labelled with digoxigeniñ 11-dUTP (Boehringer Mannheim, Indianapo lis, IN) by nick translation, precipitated if ethanol with a $50 \times$ excess of human Cot-1 ane herring testis DNA (Gibco-BRL, Gaithers్3 burg, MD), and resuspended to a final conceres tration of $20 \mathrm{ng} / \mu \mathrm{l}$ in hybridisation solution (50\% formamide, $2 \times$ SSC, $10 \%$ dextra sulphate). Probes were denatured at $76^{\circ} \mathrm{C}$ fof 10 minutes and preassociated at $37^{\circ} \mathrm{C}$ for $1 \frac{\delta}{\delta}$ minutes before hybridisation.

The probe-hybridisation $\operatorname{mix}(10 \mu \mathrm{l})$ was applied under a $22 \times 22 \mathrm{~mm}$ coverslip and slides were incubated in a moist chamber for 19 hours at $37^{\circ} \mathrm{C}$, then washed as previousfy described. ${ }^{7}$ Probes were detected with $50 \mu$ l $\overrightarrow{0 \mid}$ rhodamine anti-digoxigenin (Boehringepo Mannheim) at $1 \mu \mathrm{g} / \mu \mathrm{l}$. Slides were washed three times in $4 \times$ SSC, $0.1 \%$ Tween -20 at $45^{\circ} \mathrm{C}$ an mounted in antifade solution (Vector) contair ing DAPI. Analysis was performed using Zeiss Axiophot microscope equipped wi filters to detect DAPI and rhodamine sep然 rately, as well as a triple band pass filter (Chroma Technology Corporation) to detee signals simultaneously. Images were collectê, and merged using a cooled CCD camera (KA 1400, Photometrics) and IP Lab Spectru software (Signal Analytics Corporation).

BAC END SEQUENCING AND STS DEVELOPMENT Purified BAC DNA was isolated using Qiagen Midi-Prep columns (Chatsworth, CA) accore ing to the manufacturer's protocol, with the fof lowing modifications: Qiagen-Tip 100 columis were used for a $250 \mathrm{ml}$ overnight culture with $\mathrm{ml}$ of $\mathrm{P} 1,10 \mathrm{ml}$ of $\mathrm{P} 2$, and $10 \mathrm{ml}$ of $\mathrm{P} 3$ solutions as described elsewhere. ${ }^{15}$ One $\mu \mathrm{g}$ of BAC DN as a template and $40 \mathrm{pmol}$ of T7 and SP6 prins ers were used for sequencing reactions with ABI Prism $^{\mathrm{TM}}$ Dye or dRhodamine Terminator Cycte Sequencing Ready Reaction Kit (PE Applię Biosystems, Foster, CA). T7 and SP6 primerr sequences have been described previously. ${ }^{16} \mathrm{TP}$ sequencing reaction was cycled 50 times at $95^{\circ} \%$ for 30 seconds, $50^{\circ} \mathrm{C}$ for 30 seconds, $72^{\circ} \mathrm{C}$ 60 seconds. The Primer3 program (http://wwwegenome.wi.mit.edu/cgi-bin/primer/primer3.cgi) was used for generating new STSs from the sequences obtained. All clones used here were confirmed to contain the new STSs by PCQ using $0.1 \mu \mathrm{g}$ of BAC DNA as a template.

PULSED FIELD GEL ELECTROPHORESIS (PFGE) The Chef Mapper ${ }^{\mathrm{TM}}$ pulsed field electrophoresis system (BIO RAD, Richmond, CA) was 
Table 3 New STSs

\begin{tabular}{|c|c|c|c|}
\hline Primer name & Sequences $\left(5^{\prime} \rightarrow 3^{\prime}\right)$ & $\begin{array}{l}\text { Product size } \\
\text { (bp) }\end{array}$ & $\mathrm{Ta}\left({ }^{\circ} \mathrm{C}\right)$ \\
\hline $\begin{array}{l}136 \mathrm{I} 14-\mathrm{T} 7 \mathrm{a} \\
136 \mathrm{I} 14-\mathrm{T} 7 \mathrm{~b}\end{array}$ & $\begin{array}{l}\text { CAT GTA TGA CAA ACC CAC AGC } \\
\text { GTG GCA AGA GTG GAC ATC CT }\end{array}$ & 101 & 55 \\
\hline 253G2-T7a & AGC AAA CAG AAA AGC CCA GA & 161 & 55 \\
\hline 253G2-T7b & TGG CAA ATG TAC CTG AAG CA & & \\
\hline $\begin{array}{l}\text { 253G2-SP6a } \\
\text { 253G2-SP6b }\end{array}$ & $\begin{array}{l}\text { ATT GTC TCA CAG CTC CCT GG } \\
\text { CAC TCA CTG AAT GGG CTC AA }\end{array}$ & 155 & 55 \\
\hline $\begin{array}{l}278 \mathrm{H} 4-\mathrm{T} 7 \mathrm{a} \\
278 \mathrm{H} 4-\mathrm{T} 7 \mathrm{~b}\end{array}$ & $\begin{array}{l}\text { TTG AAC TTC AGC CGT CCT TT } \\
\text { TTG GCT GAA CAT TGA CTT GC }\end{array}$ & 284 & 55 \\
\hline $\begin{array}{l}\text { 278H4-SP6a } \\
278 \mathrm{H} 4-S P 6 b\end{array}$ & $\begin{array}{l}\text { CCA GCA ATT TGG TAA ACT GGA } \\
\text { TGC ACT TAC ACA AAG GTA CAA AA }\end{array}$ & 125 & 55 \\
\hline $\begin{array}{l}\text { 35L6-T7a } \\
\text { 35L6-T7b }\end{array}$ & $\begin{array}{l}\text { TGG GGC TTA TAT CCC CTT TC } \\
\text { ATA CCC TGC CAA TAG TCC CC }\end{array}$ & 199 & 55 \\
\hline $\begin{array}{l}\text { 35L6-SP6a } \\
\text { 35L6-SP6b }\end{array}$ & $\begin{array}{l}\text { GGG ATA TCG CTG GCA ATT TA } \\
\text { GCC ACA AGT CCA GTA GCT GA }\end{array}$ & 244 & 55 \\
\hline $\begin{array}{l}127 \mathrm{H} 8-\mathrm{T} 7 \mathrm{a} \\
127 \mathrm{H} 8-\mathrm{T} 7 \mathrm{~b}\end{array}$ & $\begin{array}{l}\text { CCA ATC ACT TTT TAT TGC ACC A } \\
\text { TGA ATG CAA TGT TTT ATT GAA CC }\end{array}$ & 196 & 55 \\
\hline $\begin{array}{l}\text { 127H8-SP6a } \\
127 \mathrm{H} 8-S P 6 b\end{array}$ & $\begin{array}{l}\text { ATT TGA ACA AGA TGG CAG GC } \\
\text { GCC TCC CAA AAG TGC TGA G }\end{array}$ & 60 & 55 \\
\hline $\begin{array}{l}162 M 18-T 7 a \\
162 M 18-T 7 b\end{array}$ & $\begin{array}{l}\text { TAA CTT GAG CAA TTC CCG GT } \\
\text { AGA TTC CTG CAG AGC CTA GC }\end{array}$ & 124 & 55 \\
\hline $\begin{array}{l}\text { 162M18-SP6a } \\
\text { 162M18-SP6b }\end{array}$ & $\begin{array}{l}\text { TTC CCA ATG TTT TCT GTG TCC } \\
\text { TGC TTT TTG GGA GGT TAA GAG }\end{array}$ & 158 & 55 \\
\hline
\end{tabular}

Ta: annealing temperature.

used for PFGE. BAC DNA was extracted by an automatic nucleic acid isolation system (AutoGen 740, Integrated Separation Systems, Natick, MA). One $\mu \mathrm{g}$ of DNA was digested with NotI for three hours and electrophoresed in a $1.0 \%$ SeaKem GTG agarose gel (FMC Bioproducts, Rockland, ME) with run conditions set by the auto algorithm to separate the size range from $5 \mathrm{~kb}$ to $300 \mathrm{~kb}$. The gel was stained with ethidium bromide.

\section{Results}

BAC CLONE ISOLATION AND FISH ANALYSIS

One to three BAC clones were isolated from a Genome Systems BAC library with region specific STS primers on the $\mathrm{X}$ chromosome as shown in table 2. Each clone contained one to three STSs. FISH using these clones on normal metaphases showed that they mapped uniquely to Xq22.3 with no evidence of chimerism (data not shown). FISH analysis of the same clones on metaphase preparations from the translocation patient showed that
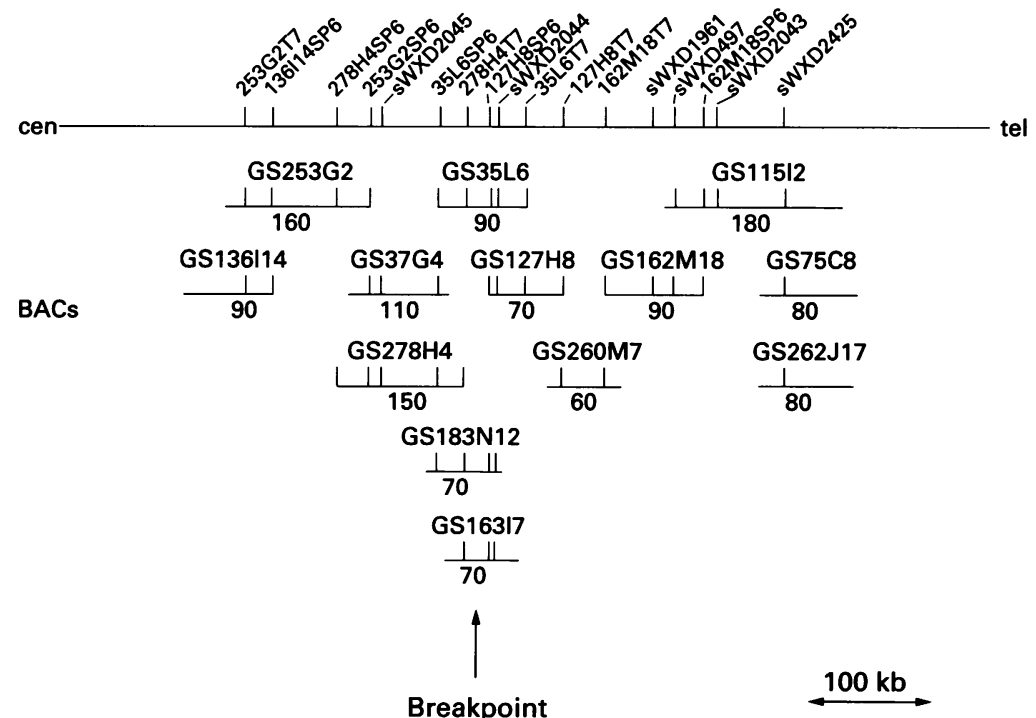

Figure 2 Physical map of a $490 \mathrm{~kb} B A C$ contig of the region around the $X q 22.3$ breakpoint of $t(X ; 2)$ in a lissencephaly patient. Anchor markers and 11 novel STS (short vertical line) are indicated at the top of the map. The breakpoint is estimated to be located in a region between STSs $278 H 4 T 7$ and sWXD2044. eight clones mapped proximal to the Xq22.3 breakpoint, five clones mapped distal to the breakpoint, and three clones mapped both proximal and distal to the breakpoint. The latter three clones therefore span the translocation breakpoint. An example of the FISH results with a breakpoint clone is shown in fig 1.

CONTIG ASSEMBLY AROUND THE BREAKPOINT Chromosome walking was performed by generating new STSs from BAC clones $278 \mathrm{H} 4$, 35L6, 127H8, and 162M18. These STSs were used to isolate the additional BAC clones $136 \mathrm{I1} 4,253 \mathrm{G} 2$, and 260M7. Of these, 136I4 and 253G2 mapped proximal to the breakpoint and 260M7 mapped distal to the breakpoint on $\mathrm{Xq} 22.2$ by FISH, with no evidence of chimerism. 136I14, 253G2, $278 \mathrm{H} 4,35 \mathrm{~L} 6,127 \mathrm{H} 8$, and $162 \mathrm{M} 18$ were sequenced from both ends of the insert DNA from the T7 and SP6 vector sequences. All ends produced $300-400 \mathrm{bp}$ of sequence, which was used to design specific primers (table 3), with the exception of the 136I14-SP6 end which contained L1 sequence. A complete contig around the breakpoint was constructed with $13 \mathrm{BAC}$ clones (fig 2). PFGE analysis showed the clone sizes ranged from $60 \mathrm{~kb}$ to $180 \mathrm{~kb}$. The contig spans at least $490 \mathrm{~kb}$ as estimated from the sizes of non-overlapping clones within the contig. The breakpoint is located between STSs $278 \mathrm{H} 4 \mathrm{~T} 7$ and sWXD2044.

\section{Discussion}

The first linkage study of XLIS/SBH showed a putative XLIS/SBH locus either at Xq22.3q23, between DXD8020 and DXS1072, or at $\mathrm{Xq27.}{ }^{12}$ Though the latter region was not excluded, the mapping of the breakpoint involved in the $\mathrm{X} ; 2$ balanced translocation to Xq22.3 strongly suggested that Xq22.3-q23 was the probable locus for XLIS/SBH. DXS8020 in Xq22.2 and DXS1072 in Xq23 defined a $9.2 \mathrm{cM}$ candidate region. A second linkage study indicated that the critical region was between Xq21.3 and Xq24, flanked by markers DXS990 and DXS1001 with a genetic distance of $22 \mathrm{cM} \cdot{ }^{13}$ Furthermore, physical mapping of the X;2 breakpoint showed that the breakpoint was located between markers DXS1105 and DXS1072, which are within 1 cM of each other. ${ }^{13}$ For isolation of clones spanning the breakpoint, we chose 14 STSs between DXS1 105 and DXS1072 using the 75 $\mathrm{kb}$ resolution map of Nagaraja et al. ${ }^{14}$ We identified one to three BAC clones corresponding to each STS. FISH analysis of these clones showed three clones, corresponding to sWSS2044, spanning the breakpoint. The availability of high resolution physical maps, such as the $75 \mathrm{~kb}$ STS resolution maps now available for chromosome $7^{17}$ and the $\mathrm{X}$ chromosome, ${ }^{14}{ }^{18}$ greatly facilitates the construction of clone contigs using BAC libraries with an average insert size of $120 \mathrm{~kb}$. These resources make it possible to construct large contigs, such as the $490 \mathrm{~kb}$ contig described here, with relatively few chromosome walking steps. The resulting physical map and clone 
contig, including three clones spanning the translocation breakpoint, will be useful for the isolation and complete genomic characterisation of the XLIS gene as well as other contiguous genes which may play a role in brain development or function.

As previously hypothesised by Ross et $a l,{ }^{13}$ it is likely that the phenotypic differences between males and females with mutations in the $X L I S$ gene are the result of Lyonisation in females. Hemizygous males have lissencephaly while heterozygous females are mosaics. Neurones with the normal allele active migrate normally, while cells with the mutant allele active fail to migrate and form the subcortical band. The thickness of the band, and consequently the clinical severity, would be dependent on the degree of skewing of the $X$ inactivation pattern.

Isolation of the $X L I S / S B H$ gene and determination of its function and relationship to LIS1 will provide valuable insights into normal cortical development as well as the pathophysiology of human neuronal migration disorders.

\section{Note added in proof}

While this manuacript was under review, the $X L I S$ gene was successfully isolated by two independent groups. ${ }^{1920}$

We express our gratitude to Ms Stephanie Mewborn for expert technical assistance with the FISH analysis. NM was supported in part by a research fellowship of Uehara Memorial Foundation.

1 Dobyns WB, Truwit CL. Lissencephaly and other malformations of cortical development: 1995 update. Neuropediatrics 1995;26:132-47.

2 Dobyns WB. Chromosome $\mathrm{X}$ and 17-linked lissencephaly (smooth brain) syndromes. Mental Retardation and Developmental Disabilities Research Reviews 1996;2:118-21.

3 Dobyns WB, Curry CJR, Hoyme HE, Turlington L, Ledbetter DH. Clinical and molecular diagnosis of MillerDieker syndrome. Am $₹$ Hum Genet 1991;48:584-94.
4 Dobyns WB, Elias ER, Newlin AC, Pagon RA, Ledbetter DH. Causal heterogeneity in isolated lissencephaly. Neurology 1992;42:1375-88.

5 Pilz DT, Quarrell OWJ. Syndromes with lissencephaly. $\mathcal{F}$ Med Genet 1996;33:319-23.

6 Pilz DT, Macha ME, Precht KS, Dobyns WB, Smith ACN Ledbetter DH. FISH analysis in 100 patients with isolated lissencephaly sequence (IIS): LIS 1 probes increase dele lissencephaly sequence (ILS): LIS1 probes increase delछ

7 Chong SS, Pack SD, Roschke AV, et al. A revision of the lis sencephaly and Miller-Dieker syndrome critical regions chromosome 17p13.3. Hum Mol Genet 1997;6:147-55.

8 Reiner O, Carrozzo $\mathrm{R}$, Shen $\mathrm{Y}$, et al. Isolation of Miller-Dieker lissencephaly gene containing G proteint beta-subunit-like repeats. Nature 1993;364:717-21.

9 Lo Nigro C, Chong SS, Smith ACM, Dobyns WB, Ledbe ter DH. Point mutations and an intragenic deletion LIS1, the lissencephaly causative gene in isolated lissencephaly sequence and Miller-Dieker syndrome. Hum Mig Genet 1997;6:157-64.

10 Fogli A, Lo Nigro C, Renieri A, et al. Mutation analysis the LIS1 gene of 14 patients with isolated lissencephaly sequence. Am F Hum Genet Suppl 1997;61:A333.

11 Dobyns WB, Andermann E, Andermann F, et al. X-linked malformations of neuronal migration. Neurology 1996;4 $\vec{t}$ 331-9.

12 des Portes V, Pinard JM, Smadja D, et al. Dominant linked subcortical laminar heterotopia and lissencepha syndrome (XSCLH/LIS): evidence for the occurrence of mutation in males and mapping of a potential locus Xq22. ₹ Med Genet 1997;34:177-83

13 Ross ME, Allen KM, Srivistava AK, et al. Linkage an physical mapping of X-linked lissencephaly/SBH (XIIS): $: \oplus$ gene causing neuronal migration defects in human braif Hum Mol Genet 1997;6:555-62.

14 Nagaraja R, MacMillan S, Kere J, et al. X chromosome mạ at 75-kb STS resolution, revealing extremes of recombination and GC content. Genome Res 1997;7:210-22.

15 Hubert RS, Mitchell S, Chen XN, et al. BAC and PAC corf tigs covering $3.5 \mathrm{Mb}$ of the Down syndrome congenita tigs covering $3.5 \mathrm{Mb}$ of the Down syndrome congenitats chromosome 21. Genomics 1997;41:218-26.

16 Matsumoto N, Soeda E, Ohashi H, et al. A 1.2-megabase BAC/PAC contig spanning the $14 \mathrm{q} 13$ breakpoint of $\mathrm{t}(2 ; 14 \phi$ in a mirror-image polydactyly patient. Genomics $1997 ; 4$ 11-16.

17 Bouffard G, Idol JR, Braden VV, et al. A physical map et human chromosome 7: an integrated YAC contig map wi average STS spacing of $79 \mathrm{~kb}$. Genome Res 1997;7:673-9

$18 \mathrm{Yu}$ J, Wong GKS. The mappers' torch song. Genome $R_{\text {git }}$ 1997;7:666-8.

19 des Portes V, Pinard JM, Billuart P, et al. A novel CNS geñ required for neuronal migration and involved in X-linkeg subcortical laminar heterotopia and lissencephaly syn drome. Cell 1998;92:51-61.

20 Gleeson JG, Allen KM, Fox JW, et al. doublecortin, brain-specific gene mutated in human $\mathrm{X}$-linked lissen cephaly and double cortex syndrome, encodes a putati离 signaling protein. Cell 1998;92:63-79. 